REVIEW OF HISTORICAL SCIENCES 2017, VOL. XVI, NO. 3

http://dx.doi.org/10.18778/1644-857X.16.03.10

ZBigniew ANUSIK

UNIVERSITY OF LODZ*

\title{
Who was countess Dorothea von Helfenstein? A contribution to the genealogy of the Kurzbach and the Helfenstein families in the $15^{\text {th }}$ century
}

$\mathrm{T}$

The protagonist of the article is countess Dorothea von Helfenstein, wife of Sigismund von Kurzbach, first baron of Żmigród and Milicz. It is an almost unknown person, the origin of whom historians have been unable to find out about until now. However, it seems to be equally interesting that as little is also known about her husband's family. Thus, before we explain the origin of countess Dorothea herself, a few words would be devoted to her more famous spouse.

In historical literature there is no information about Sigismund's parents and his youth. It is only known that he was a trusted courtier and adviser to the King of Bohemia (since 1471), Vladislaus II of Hungary. He made a staggering career at the Prague court. The events that took place between 1489-1492 turned out to be most significant in Sigismund's life. Konrad X the White, last Duke of Oleśnica (Olsen) from the Piast dynasty, fell into an open conflict with Matthias Corvinus, the king of Hungary and the ruler of Moravia, Lusatia and Silesia. In the summer of 1489, the Hungarian army took control of the duchy, removed Konrad from Oleśnica, and forced estates to pay tribute to Matthias. Konrad was transferred to the Uraz castle and granted a yearly salary of 1600 guilders. In the same year Matthias Corvinus separated from the

* The Faculty of Philosophy and History, The Institute of History, The Department of Modern History / Wydział Filozoficzno-Historyczny, Instytut Historii, Katedra Historii Nowożytnej, e-mail: zanusik@uni.lodz.pl. 
Duchy of Oleśnica (the first in Silesia) a free state country of Syców (Wartenberg), which he handed to one of his followers, Johann von Haugwitz ${ }^{1}$. After a sudden death of Matthias Corvinus, who died in Vienna on April 6, 1490, Konrad X returned to Oleśnica and began negotiations to transfer his inheritable rights to the duchy to the Legnica Piasts. However, those plans were not approved by a new ruler of Silesia, Vladislaus II of Hungary, who after the death of Matthias sat on the Hungarian throne. Already in February 1491 (according to the agreement made after a fight for the Hungarian crown), Vladislaus promised to give a large part of Silesia together with Oleśnica to his younger brother, John I Albert. Yet, because the latter broke off the agreement and resumed the fight for the Hungarian throne, which finally he lost, the Duchy of Oleśnica was not given to him at all. When Konrad X the White died childless on September 21, 1492, King Vladislaus decided to settle the matter of Konrad's inheritance otherwise. Already in 1492, the free state country of Żmigród (Trachenberg) was created from the part of the Duchy of Oleśnica, the ruler of which became the king's trusted courtier, Sigismund von Kurzbach. In 1494, Vladislaus II of Hungary extended Sigismund's authority to another part of the Duchy of Oleśnica, the newly created state country of Milicz (Militsch). Thus, in 1494 Sigismund Kurzbach was ruling an entire northern part of the former Duchy of Oleśnica with Milicz, Żmigród, Sułów (Sulau), Prusice (Prausnitz), Cieszków (Freyhan) and Nowy Zamek (Neuschloss). Kurzbach proved to be a very good host to the lands of Milicz and Żmigród, as he rebuilt those goods after the Hussite wars and subsequent unrest in Silesia. In 1512, he enlarged his Silesian estate and bought from the Hungarian magnate, count Johann Turzo, Wińsko (Winzig), Wąsosz (Herrnstadt) and Ryczeń (Rützen). As King Vladislaus still trusted him, he was nominated a commander of Buda (Ofen), where he died on November 27, 1513. According to his wish, he was buried in a church in Prusice, which he had renovated beforehand ${ }^{2}$.

${ }^{1}$ See K.G. Hoffman, Geschichte der Schleisen aus den ältesten Zeit bis aus unsere Tage, Bd. II, Schweidniz 1828, p. 464; F.G.G. Kurts, Denkwürdigkeiten aus der Geschichte der Stadt und Standesherrschaft Wartenberg, Wartenberg 1846, p. 24; R. He ck, Konrad X, [in:] Polski słownik biograficzny [further on: PSB], vol. XIII, Wrocław-Warszawa-Kraków 1967-1968, p. 595.

2 See J. Sin a pius, Schleisischer Curiositäten Erste Vorstellung, Darinnen die ansehnilchen Geschlechter Des Schleisischen Adels, Mit Erzehlung Des Ursprungs, der Wappen, Genealogien, der qualificirtesten Cavaliere, der Stamm-Häuser und 
German historians claim that Sigismund had with countess Dorothea von Helfenstein three children, two sons: Johann and Heinrich, and a daughter, Anna. It is worth reiterating some information on them. In 1514, Vladislaus II of Hungary upheld his decision that Sigismund's sons should keep their father's goods. Initially, both brothers were ruling the state of Milicz and Żmigród. In 1521, however, they divided, with the consent of King Louis II of Hungary, goods of their father. Johann took Milicz, Sułów, Cieszków together with Nowy Zamek, while Heinrich received Żmigród and Prusice. The elder of the brothers, Johann, married three times. His first wife, who he married in 1512 when his father was still alive, was Salomea, princess of Żagań (1475/76-1514), a daughter of Jan II the Med (deceased 1504), the last Duke of Żagan (Sagan) and Głogów (Glogau) of the Piast dynasty, and Catherine, Duchess of Opava, a widow of a deceased on July 12, 1511, Albrecht, Duke of Ziębice (Münsterberg) and Oleśnica. Johann's second wife was Christina von Menhold. Both above-mentioned Johann's spouses died childless. Only his third wife, Anna Zborowska, Jastrzębiec coat of arms, a daughter of Marcin (deceased 1565), later castellan of Cracow, and Anna of Góra Konarska, Awdaniec coat of arms, gave him a son, Sigismund II (1547-1579), and perhaps also a daughter, Anna. Johann von Kurzbach, baron of Milicz, died on May 18, 1549. Before 1554, a widow of him, Anna Zborowska, married for a second time to Jan Borek Gostyński, Gryzima coat of arms, a nobleman from Greater Poland. The second brother, Heinrich von Kurzbach, baron of Żmigród, married Anna von Ilburg

Güter beschrieben..., Leipzig 1720, pp. 202-203; Codex Germaniae Diplomaticus, worinnen Viele wortrefliche und zum Theil noch niemahls Borheins genommene..., Frankfurt und Leipzig 1733, pp. 446-448 (the granting of Milicz castle and its surroundings to Sigismund Kurzbach, baron of Żmigród, dated on November 30, 1494); J.C. Is elin, Neu-vermehrtes Historisch- und Geographisches Allgemeines Lexicon, Bd. III, Basel 1745, p. 61; N. Po1, Jahrbücher der Stadt Breslau, Bd. II, Breslau 1815, p. 199; L.A. Gebhard, Geschichte aller Wendisch-Slavischen Staaten, Bd. III, Basel 1797, p. 340; K.A. Mü1le r, Vaterländische Bilder, in eine Geschichte und Beschreibung den alte Burgfesten und Ritterschlösser Preussens, Glogau 1837, pp. 200-201; O.L. Goedsche, Geschichte und Statistik des Militsch-Trachenberg Kreises, Militsch-Breslau 1847; R. Heck, op. cit., p. 595; J. G a r b a cik, Jan I Olbracht, [in:] PSB, vol. X, Wrocław-Warszawa-Kraków 19621964 , p. 406. We do not know the exact date of Sigismund's birth, but it could be assumed, that he was born no earlier than 1450, and not later than 1455 . It should be also added, that in 1495 Vladislaus II of Hungary gave the remaining part of the Duchy of Oleśnica with Wołów to Henry, Duke of Ziębice, who in return gave the king his ancestry Poděbrady. 
(Elenburg) of the Czech branch of the family, a daughter of Wilhelm von Ilburg-Ronov (deceased 1538), a governor of Upper Lusatia, and Agnes von Helfenstein-Wisensteig, his mother's distant cousin. He had one son from that marriage, Wilhelm (1525-1567). The younger son of Sigismund von Kurzbach died in 1533. Anna von Kurzbach, probably the youngest child of her parents, became a nun. She died on January 30, 1560, as a prioress of the monastery of St. Clara in Wrocław ${ }^{3}$.

We must admit that on the basis of the above information it is difficult to say something more about Sigismund von Kurzbach and his wife. Thanks to the research and archive materials collected by Włodzimierz Dworzaczek we can prove, however, that Sigismund von Kurzbach and Dorothea von Helfenstein had not three, but at least four children. His second daughter, unknown to the majority of German historians, was Ludmila von Kurzbach. In my opinion, she was the eldest child of Sigismund and Dorothea. She was mentioned for a first time in two documents dating back to 1506, when she was already married to a representative of the noblemen's family of Greater Poland, Jan Bniński, Łodzia coat of arms, a son of Andrzej (deceased 1503) castellan of Kamien ${ }^{4}$. In the first of the documents, Mikołaj Kobyliński and Maciej Witkowski affirmed that Ludmila's father, Sigismund Korzbok of Witkowo, baron of Żmigród, would pay to her husband a dowry of 500 Hungarian zlotys, while Jan Bniński obliged himself to release his goods from all burdens and secure his spouse's dowry together with the bride price ${ }^{5}$. In the second, Jan Bniński secured

${ }^{3}$ See J. Sinapius, op. cit., pp. 203-205; J.C. Is elin, op. cit., p. 61; N. Pol, Jahrbücher der Stadt Breslau, Bd. IV, Breslau 1823, p. 50, pp. 98-99; K.A. M ü11 e r, op. cit., pp. 200-201; O.L. Goed sche, op. cit., pp. 10-13; W. Dworzaczek, Genealogia, vol. II (Tablice), Warszawa 1959, table 133. As it was in their father's case, we do not know birth dates of Sigismund von Kurzbach's children. However, we should be careful when matching Johann's date of birth to the date of his first wife's birthday. In my opinion, he was born around 1590, and he was probably a couple of years younger than Salomea, princess of Żagań. Heinrich and Anna were probably born in the last decade of the $15^{\text {th }}$ century.

4 See The Kórnik Library of PAN [further on: BKPAN], Dworzaczek Files [further on: TD], Monografie, Bninscy herbu Łodzia. It should be noted, that only one of the above-mentioned German historians claimed that Ludmila was a child of Sigismund von Kurzbach. Moreover, in his opinion, Sigismund had also two more daughters, Margarete and Barbara. See. N. Pol, op. cit., Bd. II, p. 199.

${ }^{5}$ See BKPAN, TD, Grodzkie i ziemskie, Poznań, Inskrypcje, XVI wiek, part 1, 411 (No. 862), 1506, f. 107v. 
600 Hungarian zlotys of a dowry and the same sum of money on his goods for a wife, Ludmila of Milicz, a daughter of Sigismund Korzbok, liberi domini of Żmigród and Milicz ${ }^{6}$. In 1520, Jan Bniński gave to his wife Ludmila, a daughter of the late Sigismund, a free lord at Żmigród and Milicz, a life tenure that consisted of the half of the town of Bnin and the adjoining villages. Moreover, in case of his death he made her brother, Johann Korzbok of Żmigród and Milicz, a guardian of their sons ${ }^{7}$. In 1524, Jan Bniński changed his wish a little and entrusted the custody of his sons and family goods to Ludmila of Milicz and her brother, Johann Korzbok, baron of Milicz ${ }^{8}$. Jan Bniński was still alive in 1534. He was recorded as a deceased in the following year. He left three sons, Stanisław, Jan and Andrzej, as well as daughters: Agnieszka, wife of Mikołaj Ksiąski, Dorota, wife of Mikołaj Malechowski of Konary, then Mikołaj Kołaczkowski of Konary, Ludmiła, wife of Andrzej Witosławski, Jadwiga, married to Jan Goliński, then to Jan (Janusz) Słomowski, Katarzyna, married to Stanisław Siedlecki, and Barbara, married to Stanisław Dobrzycki ${ }^{9}$. In 1545 , the widow of Jan was already ill, thus she gave from her heritage secured on the goods of Borek 100 zlotys to each of her elder daughters: Agnieszka, Dorota, Ludmiła, Jadwiga and Katarzyna, and 200 zlotys to the youngest Barbara $^{10}$. Ludmiła Bnińska of Milicz probably died shortly after. She was no longer alive in $1549^{11}$.

The Greater Poland's records confirm that Sigismund von Kurzbach, a free lord at Milicz and Żmigród, was a Polish nobleman ${ }^{12}$.

${ }^{6}$ See BKPAN, TD, Grodzkie i ziemskie, Poznań, Rezygnacje, XV wiek, part 1, 7258 (No. 1390), 1506, f. 80v. It should be noted, that Jan Bniński secured the dowry and the bride price on a third part of the town of Borek, a third part of villages of Skokowo, Zdziesz, Trzecianowo and Stawiszynek, a sixth part of villages of Bruczkowo and Zalesie, and an entire village of Bartoszewice. See also ibidem, Monografie, Bnińscy herbu Łodzia.

7 See BKPAN, TD, Grodzkie i ziemskie, Poznań, Rezygnacje, XVI wiek, 4678 (No. 1392), 1520, f. 368v; and ibidem, Monografie, Bninscy herbu Łodzia.

8 See BKPAN, TD, Grodzkie i ziemskie, Poznań, Rezygnacje, XVI wiek, 5449 (No. 1393), 1524, f. 38v.

9 See BKPAN, TD, Monografie, Bnińscy herbu Łodzia.

${ }^{10}$ See BKPAN, TD, Grodzkie i ziemskie, Rezygnacje, XVI wiek, 2745 (No. 1395), 1545, f. 225.

${ }^{11}$ See BKPAN, TD, Monografie, Bnińscy herbu Łodzia.

${ }^{12}$ The fact was also known to some German historians. O.L. Goedsche reported, that in 1514 Sigismund's sons sold Witkowo and other father's goods in the Gniezno district for 100 guilders to their "paternal uncle", Matthias Kurzbach. See idem, op. cit., p. 10. We should mention here, that the Kurzbach family was 
Thanks to those sources we also know who were his parents. We should underline, that in the already quoted documents of 1506 he was known as Korzbok of Witkowo. He used that name before, too. In 1485, Sigismund Korzbok Witkowski sold to Władysław of Głęboczek, a doctor of decrees and a canon of Poznań and Gniezno, inheritable parts of villages Grzybowo, Wołowe and Suchodól, which he had purchased for 50 grzywnas from Stanisław Broniew$\mathrm{ski}^{13}$. In the following year the same Sigismund, a son of the already deceased Piotr Witkowski, went to law with brothers Jan and Stanisław of Gurów ${ }^{14}$. It confirms that the later baron of Milicz and Żmigród came from the Korzbok family of Witkowo in the Gniezno district. He was a son of Piotr Korzbok of Witkowo (deceased after 1486), who was recorded in the books of Poznań in 1449-148015. Ludmiła Głębocka of Głęboczek, Łodzia coat of arms, a daughter of Piotr (deceased after 1453), a castellan of Rogoźno, was Piotr's wife and undoubtedly the mother of Sigismund. It was she, a daughter of the late Piotr Głębocki and a wife of Piotr Witkowski, to sue Paweł Budziszewski in 1475 for ius propinquitatis to goods of Głęboczek formerly owned by her father and mother ${ }^{16}$. In 1486, being already a widow of Piotr Korzbok of Witkowo, she went to law with Jan Korzbok of Rybno, where Mikołaj of Kutno, the voivode of Lęczyca and a general starost of Greater Poland,

bearing Korzbok coat of arms: "Three golden carps... one over another, swimming in the white background, five ostrich feathers on the helmet”. See K. Niesiecki, Herbarz polski, ed. J.N. Bobrowicz, vol. V, Lipsk 1840, p. 257. It is worth adding, that sometimes the coat of arms in question had blue or red background, and no carps, but other fish on it.

${ }^{13}$ See BKPAN, TD, Grodzkie i ziemskie, Poznań, Rezygnacje, XV wiek, part 1, 5771 (No. 1387), 1485, f. 16.

14 See BKPAN, TD, Grodzkie i ziemskie, Gniezno, part 2, 2264 (No. 22), 1486, f. 43 .

15 See BKPAN, TD, Grodzkie i ziemskie, Gniezno, part 2, 1774 (No. 7), 1449, f. 14v; Grodzkie i ziemskie, Poznań, Rezygnacje, XV wiek, part 1, 388 (No. 1381), 1450, f. 103; 2725 (No. 20), 1468, f. 159v; 9642 (No. 9 gr. 1386), 1480, f. 198v. It is totally unacceptable to identify father of Sigismund Korzbok of Milicz with Piotr Korzbok (deceased 1438), a chamberlain of Poznań. It cannot be excluded, though, that Piotr Korzbok of Witkowo could have been the grandson of the chamberlain. See A. Gas siorowski, Korzbok (Korczbok, Korczborg) Piotr, [in:] PSB, vol. XIV, Wrocław-Warszawa-Kraków 1968-1969, p. 159.

16 See BKPAN, TD, Grodzkie i ziemskie, Rezygnacje, XV wiek, part 2, 854 (No. 21zs), 1475, f. 23v. More information on Ludmila's father, the castellan of Rogoźno, Piotr Głębocki see Słownik historyczno-geograficzny województwa poznańskiego $w$ średniowieczu, part 1, eds S. Chmielewski, K. Górska-Gołaska, J. Luciński, Wrocław 1982-1987, p. 485. 
Sędziwój Czarnkowski, a castellan of Santok, and Maciej Słupski, a castellan of Nakło, were arbiters ${ }^{17}$. Therefore, we may state once again that the first ruler at Milicz and Żmigród came from Greater Poland and was undoubtedly a son of Piotr Korzbok of Witkowo and Ludmiła Głębocka, a daughter of Piotr, castellan of Rogoźno. Sigismund Korzbok's (consistently called Kurzbach in German historiography) eldest daughter, who after marriage with Jan Bniński returned to her fatherland forever, received her name (very rare at that time among the gentry of Greater Poland) after her grandmother.

Having explained the origins of Sigismund Korzbok vel Kurzbach, we may try to answer the question posed in a title of the article. Taking into account German historiography, I assume that countess Dorothea von Helfenstein was a wife of the first baron of Milicz and Żmigród. But before we discuss her genealogy, we must dispel the doubts of an essential nature and answer the question: how Vladislaus II of Hungary's courtier, who at the beginning of his career was active mainly in the Czech Kingdom (Bohemia), married a representative of the family that had their goods in relatively remote Swabia? Fortunately, the answer is simple. The impoverished von Helfenstein family was in close relations with the Franconian Hohenzollern line, lords of Ansbach, whose representatives also held the dignity of the Brandenburg electors. The male descendants of the clan were working for margraves, while countesses became ladies in waiting at their courts. We know for sure that representatives of the von Helfenstein family were at courts of Frederick II the Iron, an elector of Brandenburg between 1440-1471, and his younger brother, Albrecht III Achilles, a margrave at Ansbach from 1440 , and an elector of Brandenburg in 1471-1486 ${ }^{18}$. Relations between the von Helfenstein family and lords at Ansbach allow us to find a clue to the marriage of Sigismund Korzbok of Witkowo with countess Dorothea. On August 20, 1476, at Frankfurt (Oder) Vladislaus II of Hungary married per procura a twelve-year-old widow of Duke Henry XI of Głogów, Barbara Hohenzollern, a daughter of a Brandenburg margrave, Albrecht III Achilles. Although the marriage was not fulfilled and the spouses never met, as Vladislaus

17 See BKPAN, TD, Grodzkie i ziemskie, Gniezno, part 2, 2218 (No. 22), 1486, f. 19.

18 See K. Gruber, Heiratsfrage als Problem, "Geislinger Zeitung", February 25, 2015, Südwest Presse online; idem, Sorge um das Lehen, ibidem, March 13, 2015; id e m, 300 Gulden bei Heirat, ibidem, March 5, 2015. 
quickly lost interest in the relationship (he married with the idea of incorporating the Duchy of Głogów into a royal domain, but it was finally taken over by a Duke of Żagań, Jan II the Mad), the Czech king's attempts of its annulment continued until the end of the $15^{\text {th }}$ century ${ }^{19}$. Less than three years later, on February 14, 1479, at Frankfurt (Oder) Frederick I of Ansbach and Bayreuth, the younger son of Albrecht III Achilles, married Sophia Jagiellon, a sister of the Czech King Vladislaus II and a daughter of King Casimir IV Jagiellon ${ }^{20}$. As expected, that marriage also contributed to the revival of relations between the Prague court and the margraves at Ansbach. Perhaps Sigismund Korzbok of Witkowo, an envoy of the Czech king, met his future wife, countess Dorothea von Helfenstein, a lady in waiting of Sophia Jagiellon, during one of his visits to the Hohenzollern court? It seems very likely.

As we see, a wife of the first baron at Milicz and Żmigród could have come from the Helfenstein family. Thus, the history of that family is worth mentioning. Its name comes from the Helfenstein castle located near Geislingen an der Steige in the Swabian Jura. Counts bore a silver elephant over three golden hills on a red background as their coat of arms. They were most significant in the $13^{\text {th }}$ and $14^{\text {th }}$ century. In 1356 , the county was divided. Ulrich V the Elder, count von Helfenstein (from 1340), ceded some of his goods and took the title of count von Helfenstein-Wiesensteig (between 1356-1372). The elder line of the von Helfenstein family derives from him. Ulrich V's cousin, Ulrich VI the Younger (deceased 1361), a progenitor of the second, younger branch of the family, became in 1356 the first count von Helfenstein-Blaubeuren ${ }^{21}$. At the end of

${ }^{19}$ See C. Grünhagen, Barbara, Markgräfin von Brandenburg, [in:] Allgemeine Deutsche Biographie, Bd. II, Leipzig 1875, pp. 49-50; K. Pieradzka, Henryk XI, [in:] PSB, vol. IX, Wrocław-Warszawa-Kraków 1960-1961, p. 415. We should add here, that Vladislaus II attempted to annul his marriage, but the Elector of Brandenburg was consistent in paralyzing his attempts, as he was aiming at his daughter sitting on the Czech throne. All that revived diplomatic relations between the Prague court and the Hohenzollern family. It is also worth mentioning, that in 1490, while still being a husband of Barbara, the Czech king married Beatrice of Aragon, the widow of Matthias Corvinus. Both marriages were annulled by Pope Alexander VI in 1500.

${ }^{20}$ See Z. W dow is zew ski, Genealogia Jagiellonów i Domu Wazów w Polsce, $2^{\text {nd }}$ ed., Kraków 2005, pp. 110-112; U. B orkow s ka, Dynastia Jagiellonów w Polsce, Warszawa 2011, p. 517.

${ }^{21}$ See H.F. Kerle r, Geschichte der Grafen von Helfenstein, Ulm 1840, pp. 1-54, especially 55-56 (here information about a division of the county and goods that 
the $14^{\text {th }}$ century the von Helfenstein family, that had many goods in Swabia, began to fall into financial difficulties. As early as 1382, Friedrich I, count von Helfenstein-Wiesensteig, took a loan in a free city of Ulm which he secured on an ancestral castle and a county of Geislingen. In subsequent years he took more loans. When finally in 1396 the municipal council of Ulm demanded him to repay money he had borrowed, it turned out that the count's debt amounted to an enormous amount of almost 124 thousand guilders. As Friedrich did not have such an amount of money, he was obliged to give away the Helfenstein castle together with Geislingen and nearly 30 villages of that county to his creditors ${ }^{22}$. In the first half of the $15^{\text {th }}$ century representatives of a younger branch of the family also indebted their assets in a similar way. In the years 1447-1448, pressed by increasingly insolvent creditors, counts Ulrich VIII and Konrad II von Helfenstein-Blaubeuren sold a significant majority of their goods to the rulers of Württemberg ${ }^{23}$. It means that in the middle of the $15^{\text {th }}$ century both branches of the von Helfenstein family lost much of their estates, thus losing their influence and political importance. In the mid-eighties of the $15^{\text {th }}$ century it gave the opportunity to Sigismund Korzbok of Witkowo, a rather poor royal courtier of the Czech king, to successfully court the representative of that once great, but already degraded family.

Another obstacle we must overcome when solving a problem of countess Dorothea's origin is the fact, that no genealogy of the von Helfenstein family confirms her existence. Yet, it is not a decisive argument. It was often that a daughter who had early left a family house was not recorded in sources of that time. In various genealogies it was common to ignore those daughters, who had become nuns. It was even common not to mention women, who had left clear evidence of their existence. We could mention

were given to counts of Wiesensteig and Blaubeuren). See also Graf Helffensteinischer Theil-Bref der Graf und Herrschaft Helfenstein, de 1356, Urkunden zur Geschichte der Grafen von Helfenstein, hrsg. von H.F. Kerler [further on: Ker1er, Urkunden], Ulm 1840, pp. 11-12; and Graf Helffensteinischer Theil-Bref der Graf und Herrschaft Helffenstein, de Anno 1356 vidimirt de Anno 1360, ibidem, pp. 12-14.

${ }^{22}$ See H.F. Kerler, op. cit., pp. 80-88; and Graff Helffensteinicher Berglich, Berzücht und Ubergab der alleniret Helffensteinischer Gütter, gegen der Stadt Ulm, de Anno 1396, Kerler, Urkunden, pp. 23-33.

${ }^{23}$ See H.F. Kerler, op. cit., pp. 97-98, p. 101; and Extract des Kaufbriefs von Blaubeuren vom Jahr 1447, Ke rle r, Urkunden, pp. 33-34. 
here, for example, the case of Anna of the Lanckoronski family $1^{\circ}$ voto Świerszcz, $2^{\circ}$ voto Piasecka, $3^{\circ}$ voto Herburt, that cannot be found in any genealogy of a well-known Lanckoroński family, Zadora coat of arms ${ }^{24}$. Unlike other researchers, who tried to find out Dorothea's parents without paying attention to the chronology of events, I have extremely important information about a date of her daughter's wedding. I assume that since Ludmila Korzbok of Milicz married Jan Bniński in 1506 or 1505, she must have been born in 1490 the latest. Probably her date of birth should be moved to even 1487 or 1488. It means that her mother, countess Dorothea von Helfenstein, was probably born between 1465 and 1470, and married Sigismund Korzbok in 1485 or 1486. This, in turn, allows us to narrow down the search area drastically.

First of all, we will make a negative selection, excluding those members of the von Helfenstein family, who lived in the sixties and seventies of the $15^{\text {th }}$ century, but could not be the father of the countess of interest. At that time the elder line of the family was represented by three adult men: Ludwig III, his younger brother Friedrich II, and a son of the latter, Ludwig IV. The oldest of them was Ludwig III, count von Helfenstein-Wiesensteig (deceased 1493), a son of Friedrich I (deceased 1438), a grandson of Ulrich V the Younger. In 1472, he married countess Amalia von Oettingen-Wallerstein (deceased 1487/1501). An old couple (at the time of his wedding Ludwig was about 60 years old) was childless ${ }^{25}$. Ludwig III's younger brother, Friedrich II (deceased 1483), married twice. Firstly, he married Agnes von Eberstein (deceased 1456), with whom he had a son, Ludwig IV (1447-1493). In 1476, Irmengard (Irmgard), countess von Helfenstein-Blaubeuren, who gave birth to Friedrich III, became the second wife of Friedrich ${ }^{26}$. Friedrich II's first wife died too early to be Dorothea's mother. His

${ }^{24}$ See Z. Anusik, Zapomniana panna Lanckorońska. Przyczynek do genealogii kilku rodzin kresowych, "Przegląd Nauk Historycznych" 2017, vol. XVI, No. 1, pp. 301-324.

${ }^{25}$ See H.F. Kerler, op. cit., pp. 115-116; D. Schwennicke, Europäische Stammtafeln. Stammtafeln zur Geschichte der Europäische Staten, Neue Folge [further on: Europäische Stammtafeln], Bd. XII (Schwaben), Marburg 1992, Tafel 58; H. B ü chle r, Adel, Klöster und Burgherren ins alten Herzogtum Schwaben, Gesammelte Aufsätze, hrsg. von W. Ziegler, Weissenhom 1997, p. 967.

${ }^{26}$ See H.F. Kerler, op. cit., pp. 118-124; Europäische Stammtafeln, Bd. XII, Tafel 58, 60 (concerns second wife of count Friedrich); Bd. XVI (Bayern und Franken), Marburg 1995, Tafel 29 (concerns first wife of count Friedrich); H. Bü chler, op. cit., p. 966. 
second wife could not have been her mother either, as she married Friedrich II too late. The youngest of the three, Ludwig IV, count von Helfenstein-Wiesensteig, was the only son of Friedrich II and his first wife, Agnes von Eberstein. In 1483, he married Elisabeth von Limpurg-Speckfeld (deceased 1538), a daughter of Georg II and Margarete von Zollern-Hohenberg. He had many children with her, the sons: Ulrich X (1486-1548), Ludwig who died in the childhood (1488-1489), and once again Ludwig, known as Ludwig V Helferich (1493-1525), as well as daughters: earlier mentioned Agnes (14841525), who in 1500 married Wilhelm von Ilburg-Ronov, Margarete (born 1489), who in 1506 married Oswald, baron von Wolkenstein, Barbara (1490-1557), and Apolonia (1492-1537). Two youngest daughters of Ludwig IV were nuns. In 1495, a widow of Ludwig IV, count von Helfenstein-Wiesensteig, married Georg I, count von Helfenstein-Blaubeuren, a distant cousin of her first husband ${ }^{27}$. For obvious reasons Ludwig IV von Helfenstein-Wiesensteig could not have been Dorothea's father. Thus, it is curious that authors of one of the most popular genealogical websites in Poland, while taking into account findings of an unidentified (probably English) genealogist, who was looking for ancestors of Charles, prince of Wales and his wife, Diana Spencer, assumed that Dorothea von Helfenstein, a wife of Sigismund Kurzbach, baron of Milicz and Żmigród, was one of the daughters of Ludwig IV and Elizabeth von Limpurg-Speckfeld $^{28}$. To neglect their findings is enough to say that, judging by

${ }^{27}$ See H.F. Kerler, op. cit., pp. 124-125; Europäische Stammtafeln, Bd. XII, Tafel 58; Bd. XVI, Tafel 140 (concerns wife of count Ludwig). H. Bü chle r, op. cit., p. 967. It should be noted here, that Elisabeth von Limpurg-Speckfeld was the only wife of Ludwig IV. Some Internet sources give untrue information that his first wife was Amalia von Oettingen-Wallerstein. She was the wife of his paternal uncle, Ludwig III, which is evidently stated in an above-quoted work of H. Büchler.

${ }^{28}$ See Urszula Ledóchowska - królewskie pochodzenie, Genealogia Polaków, Dynamiczny Herbarz Rodzin Polskich, http:/ /genealogia.okiem.pl/tron/ledochow ska_urszula.htm (online: November 15, 2017). It should be added, that the genealogy of St. Ursula Ledóchowska is based on wrong assumptions. Firstly, Dorothea von Helfenstein certainly was not a daughter of parents mentioned here. What is more, Anna von Henneberg was not the mother of one of Dorothea's ancestors, count Ulrich II (VI), as the authors claim. It was an unknown woman from the von Ravenstein family. This, in turn, makes it impossible for Mieszko III the Old to be one of Ursula Ledóchowska's ancestors. It does not mean that there were no representatives of the Polish ruling dynasty among ancestors of Dorothea von Helfenstein. According to my findings, her ancestors in the eighth generation were Ulrich I, count of Württemberg, and Agnieszka, princess of Legnica, a daughter of famous Bolesław II the Horned. 
the date of her parents' marriage, Elizabeth von Limpurg-Speckfeld was born no earlier than 1466 . Thus, she probably was at the same age as her supposed daughter.

The younger branch of the von Helfenstein family was represented in the sixties and seventies of the $15^{\text {th }}$ century by three adult men as well. The oldest was Ulrich VIII, count von Helfenstein-Blaubeuren (c. 1408-1503), son of Johann II (deceased 1444), and countess Irmgard von Kirchberg, a grandson of Ulrich VI the Younger. He was, however, a bachelor and, therefore, could not be considered as a potential father of countess Dorothea ${ }^{29}$. We could also exclude his nephew, Georg I (deceased 1517). He married for the first time in 1476. His wife was Cecilie von Truchtelfingen, a widow of Johann von Hexennager. When his first wife died childless, in 1495 count Georg married Elisabeth von Limpurg-Speckfeld, a widow of Ludwig IV, count von Helfenstein-Wiesensteig. He had with her two sons, both named Wilhelm, who died in a childhood, as well as daughters: Ursula (1496-1576), a prioress in the Kirchheim unter Teck monastery, then Magdalena (born 1497), Agata (born 1502), Dorothea (born 1503), and Anna, who all died in their childhood, and finally Wandelberg (born 1509), a future wife of Friedrich, baron von Schwarzenberg ${ }^{30}$. As we see, both marriages of count Georg were concluded too late for him to be Dorothea's father.

The only male descendant of the von Helfenstein family, who could have been the father of Sigismund Kurzbach's of Milicz and Żmigród wife was count Konrad II von Helfenstein-Blaubeuren (deceased 1474), a younger brother of Ulrich VIII, and a father of Georg I. He was born around 1410 as a second son of Johann II, count von Helfenstein-Blaubeuren, and Irmgard von Kirchberg. It seems, that originally he was meant to join the clergy, as in 1425 he became a canon at the Strasbourg Cathedral. Quite soon he abandoned that path of career, though. In 1445, a year after his father's death, he and his elder brother divided the family fortune. Konrad took Blaubeuren, and Ulrich took Brenztal. Pretty soon brothers began to sell heavily indebted lands inherited from their ancestors. Initially, they were selling single villages only. Yet, already in 1447, Konrad sold entire Blaubeuren to Ludwig, count of Württemberg

${ }^{29}$ See H.F. Kerler, op. cit., pp. 97-101; Europäische Stammtafeln, Bd. XII, Tafel 60 .

${ }^{30}$ See H.F. Kerler, op. cit., pp. 102-104; Europäische Stammtafeln, Bd. XII, Tafel 60; Bd. XVI, Tafel 140 (concerns second wife of count Georg). 
of the Urach line of the family, while in the beginning of 1448 Ulrich sold Brenztal to Ulrich, count of Württemberg of the Stuttgart line of the family. In the same year count Konrad bought a small Wellheim estate for four thousand guilders, a fief of the Brandenburg margraves at Ansbach, which since then had been the main property of that line of the family. Thus, when taking into account their properties, counts von Helfenstein could be regarded as a middle-class nobility only. Until recently it was thought that Konrad II had only one wife, Ursula von Seckendorff, who was supposed to be a mother of all his numerous children. Authors of various genealogies of counts von Helfenstein believe, that count Konrad had five sons, and at least five daughters. They do not exclude, however, that he could also have had sons Christoph and Friedrich, as well as a daughter, Ursula ${ }^{31}$. In my opinion, we should also add countess Dorothea to that register. However, here appears another doubt. As no genealogy of Konrad II von Helfenstein-Blaubeuren's family gives his date of marriage, we may assume, that the count, who was born in about 1410, could have already been married in the thirties of the $15^{\text {th }}$ century. Here arises another question. Is it possible that his wife, born around 1420, could have been the mother of a daughter, who was born almost 50 years later? Fortunately, German historian Karlfriedrich Gruber found sources that cast a new light on the family of the lord at Wellheim. It turns out that count Konrad II was married not once, but twice. He married his first wife, Dorothea von Seckendorff-Abardar (deceased 1455), between 1442 and 1448. After the death of his first wife, on August 11, 1456, the count married Ursula von Seckendorff-Rinhofen. K. Gruber claims, that it is impossible to determine which Konrad's children (he mentions five sons and five daughters) came from the first, and which from the second marriage ${ }^{32}$. But I will risk the statement, that Dorothea von Seckendorff-Abardar was a mother of his four or five daughters, and Ursula von Seckendorff-Rinhoffen was a mother of all his sons and two youngest daughters.

In this case it is enough to refer to the chronology. The first daughter of count Konrad was Sibylle, who in 1467 became a Benedictine nun at the Fraumünsters monastery in Zurich. In 1484, she

${ }^{31}$ See H.F. Kerler, op. cit., pp. 99-101, p. 104; Europäische Stammtafeln, Bd. XII, Tafel 60; H. Bü chler, op. cit., p. 316, 179, 418, pp. 432-433, p. 568, 673, 964, 1096; K. Gruber, Sorge um das Lehen.

${ }^{32}$ See K. Gruber, 300 Gulden bei Heirat; id e m, Sorge um das Lehen. 
became its prioress. She died on May 11, 1487. She was certainly a daughter of Konrad II's first wife. If her mother had been Ursula von Seckendorff-Rinhoffen, she would have entered the monastery as a ten-year-old girl at best, which must be excluded. The second daughter of count of Wellheim was Cecilie, who became a nun in the same monastery as Sibylle. The third was Anna, who became a Dominican and joined the Mariental monastery in Steinheim an der Murr. In 1478, she became its twentieth prioress ${ }^{33}$. The fourth daughter of Konrad II was Magdalena. K. Gruber thinks she was the youngest daughter of the count from his second marriage. However, it is impossible. We know that Magdalena was a servant-maid of Anna, the second wife of margrave Albrecht III Achilles, and that in 1471 she moved with her mistress from Ansbach to Berlin. Already during her stay in Franconia the young countess made a promise, that she would marry a representative of the not so prominent noble family, Heinrich von Selbitz. An attempt to annul that promise (and perhaps even a secret marriage) was the subject of the Elector of Brandenburg's diplomacy at least until $1474^{34}$. If Magdalena had really been Ursula von Seckendorff-Rinhofen's daughter, she would have been born around 1460 the earliest (after Georg and Irmengard, who are undoubtedly her eldest siblings ${ }^{35}$. It is difficult to imagine that as a ten- or eleven-year-old she could have made any binding promises. Thus, we may assume that Magdalena was the fourth, and perhaps the youngest daughter of count Konrad from his marriage with Dorothea von Seckendorff-Abardar ${ }^{36}$.

The eldest son of Konrad II from his second marriage was, already mentioned, Georg I. He was probably born in 1457, and died in 1517 as the last male descendant of counts von Helfenstein at

${ }^{33}$ See Europäische Stammtafeln, Bd. XII, Tafel 60; K. Gruber, Im "Spital des Adels", "Geislinger Zeitung”, February 18, 2015, Südwest Presse online.

${ }^{34}$ See K. Gruber, Heiratsfrage als Problem.

${ }^{35}$ I assume, that Georg I was the eldest son of Konrad II and Ursula von Sekkendorff-Rinhoffen. The name of his eldest daughter, Ursula, is a proof of it. He was probably born in 1457, because already in 1476 (at the age of 19), he married for the first time. Irmengard was probably his sister (Georg found her a husband, which involved the need to pay a dowry). She had to be born soon after him, because in the same year, 1476, at the age of seventeen or eighteen, she married count Friedrich II von Helfenstein-Wiesensteig. Thus, another child of Konrad II and his second wife could have been born around 1460 the earliest.

${ }^{36}$ It could not be excluded that countess Ursula von Helfenstein, about whom we know nothing more, was a daughter of count Konrad from his first marriage, if she really was his daughter at all. 
Blaubeuren and Wellheim. His younger brothers were: Bernard, Johann, Ernest (deceased 1483), a canon in Augsburg, Wolfgang, and perhaps Friedrich, as well as Christopher, a canon in Regensburg ${ }^{37}$. They all died at an early age and none of them left the offspring. The sister of Georg I was, also already mentioned, Irmengard. Perhaps the youngest child, and certainly the youngest daughter of Konrad II and Ursula von Seckendorff-Rinhofen, was countess Dorothea. She quickly became an orphan, as Ursula died on November 28, and Konrad died on December 14, 1474. Probably shortly after her parents' death she left the family house and became a protégée of the Elector of Brandenburg and margrave at Ansbach, Albrecht III Achilles. We can only guess, what was her further fate. Yet, if Sigismund Kurzbach's, baron of Milicz and Żmigród, wife actually came from the von Helfenstein family, she must have been a daughter of Konrad II of Wellheim, and his second wife, Ursula von Seckendorff-Rinhofen.

\section{Bibliography}

\section{Printed sources}

The Kórnik Library of PAN, Dworzaczek Files (Biblioteka Kórnicka PAN) [BKPAN]

Codex Germaniae Diplomaticus, worinnen Viele wortrefliche und zum Theil noch niemahls Borheins genommene..., Frankfurt und Leipzig 1733.

Urkunden zur Geschichte der Grafen von Helfenstein, hrsg. von H.F. Kerler, Ulm 1840.

\section{STudies}

Anusik Z., Zapomniana panna Lanckorońska. Przyczynek do genealogii kilku rodzin kresowych, "Przegląd Nauk Historycznych" 2017, vol. XVI, No. 1, pp. 301-324.

Biblioteka Kórnicka PAN, Teki Dworzaczka, Monografie, Bnińscy herbu Łodzia.

Borkowska U., Dynastia Jagiellonów w Polsce, Warszawa 2011.

Büchler H., Adel, Klöster und Burgherren ins alten Herzogtum Schwaben, Gesammelte Aufsätze, hrsg. von W. Ziegler, Weissenhom 1997.

Dworzaczek W., Genealogia, vol. II (Tablice), Warszawa 1959.

Garbacik J., Jan I Olbracht, [in:] Polski słownik biograficzny, vol. X, Wrocław-Warszawa-Kraków 1962-1964, pp. 405-410.

Gąsiorowski A., Korzbok (Korczbok, Korczborg) Piotr, [in:] Polski słownik biograficzny, vol. XIV, Wrocław-Warszawa-Kraków 1968-1969, pp. 159-160.

${ }^{37}$ See H.F. Kerler, op. cit., p. 104; Europäische Stammtafeln, Bd. XII, Tafel 60. 
Gebhard L.A., Geschichte aller Wendisch-Slavischen Staaten, Bd. III, Basel 1797.

Goedsche O.L., Geschichte und Statistik des Militsch-Trachenberg Kreises, Militsch-Breslau 1847.

Gruber K., 300 Gulden bei Heirat, "Geislinger Zeitung”, March 5, 2015, Südwest Presse online.

Gruber K., Heiratsfrage als Problem, "Geislinger Zeitung", February 25, 2015, Südwest Presse online.

Gruber K., Im “Spital des Adels”, “Geislinger Zeitung”, February 18, 2015, Südwest Presse online.

Gruber K., Sorge um das Lehen, "Geislinger Zeitung”, March 13, 2015, Südwest Presse online.

Grünhagen C., Barbara, Markgräfin von Brandenburg, [in:] Allgemeine Deutsche Biographie, Bd. II, Leipzig 1875, pp. 49-50.

Heck R., Konrad X, [in:] Polski słownik biograficzny, vol. XIII, Wrocław-WarszawaKraków 1967-1968, p. 595.

Hoffman K.G., Geschichte der Schleisen aus den ältesten Zeit bis aus unsere Tage, Bd. II, Schweidniz 1828.

Iselin J.C., Neu-vermehrtes Historisch- und Geographisches Allgemeines Lexicon, Bd. III, Basel 1745.

Kerler H.F., Geschichte der Grafen von Helfenstein, Ulm 1840.

Kurts F.G.G., Denkwürdigkeiten aus der Geschichte der Stadt und Standesherrschaft Wartenberg, Wartenberg 1846.

Müller K.A., Vaterländische Bilder, in eine Geschichte und Beschreibung den alte Burgfesten und Ritterschlösser Preussens, Glogau 1837.

Niesiecki K., Herbarz polski, ed. J.N. Bobrowicz, vol. V, Lipsk 1840.

Pieradzka K., Henryk XI, [in:] Polski słownik biograficzny, vol. IX, Wrocław-Warszawa-Kraków 1960-1961, p. 415.

Pol N., Jahrbücher der Stadt Breslau, Bd. II, Breslau 1815; Bd. IV, Breslau 1823.

Schwennicke D., Europäische Stammtafeln. Stammtafeln zur Geschichte der Europäische Staten, Neue Folge, Bd. XII (Schwaben), Marburg 1992; Bd. XVI (Bayern und Franken), Marburg 1995.

Sinapius J., Schleisischer Curiositäten Erste Vorstellung, Darinnen die ansehnilchen Geschlechter Des Schleisischen Adels, Mit Erzehlung Des Ursprungs, der Wappen, Genealogien, der qualificirtesten Cavaliere, der Stamm-Häuser und Güter beschrieben..., Leipzig 1720.

Słownik historyczno-geograficzny województwa poznańskiego w średniowieczu, part 1, eds S. Chmielewski, K. Górska-Gołaska, J. Luciński, Wrocław 19821987.

Urszula Ledóchowska - królewskie pochodzenie, Genealogia Polaków, Dynamiczny Herbarz Rodzin Polskich, http://genealogia.okiem.pl/tron/ledochowska_ urszula.htm (online: November 15, 2017).

Wdowiszewski Z., Genealogia Jagiellonów i Domu Wazów w Polsce, ed. 2, Kraków 2005. 